\title{
STX2171, a 17 $\beta$-hydroxysteroid dehydrogenase type 3 inhibitor, is efficacious in vivo in a novel hormone-dependent prostate cancer model
}

\author{
Joanna M Day*, Paul A Foster, ${ }^{1, *}$, Helena J Tutill, Fabien Schmidlin², \\ Christopher M Sharland ${ }^{3}$, Jonathan D Hargrave ${ }^{3}$, Nigel Vicker ${ }^{3}$, Barry V L Potter ${ }^{3}$, \\ Michael J Reed and Atul Purohit
}

Oncology Drug Discovery and Women's Health Group, Division of Diabetes, Endocrinology and Metabolism, and Sterix Ltd., Imperial College London, London W12 ONN, UK

${ }^{1}$ School of Clinical and Experimental Medicine, Centre for Endocrinology, Diabetes, and Metabolism, University of Birmingham, Birmingham B15 2TT, UK

${ }^{2}$ IPSEN, 5 Avenue du Canada, 91966 Les Ulis Cedex, France

${ }^{3}$ Medicinal Chemistry, Department of Pharmacy and Pharmacology, University of Bath, Bath BA2 7AY, UK

*(J M Day and P A Foster contributed equally to this work)
Correspondence should be addressed to P A Foster Email

p.a.foster@bham.ac.uk

\begin{abstract}
$17 \beta$-Hydroxysteroid dehydrogenases (17 $\beta$-HSDs) catalyse the 17-position reduction/oxidation of steroids. $17 \beta-H S D$ type 3 (17 $\beta$-HSD3) catalyses the reduction of the weakly androgenic androstenedione (adione) to testosterone, suggesting that specific inhibitors of 17 $\beta-$ HSD3 may have a role in the treatment of hormone-dependent prostate cancer and benign prostate hyperplasia. STX2171 is a novel selective non-steroidal 17 $\beta$-HSD3 inhibitor with an $\mathrm{IC}_{50}$ of $\sim 200 \mathrm{nM}$ in a whole-cell assay. It inhibits adione-stimulated proliferation of $17 \beta$-HSD3-expressing androgen receptor-positive LNCaP(HSD3) prostate cancer cells in vitro. An androgen-stimulated LNCaP(HSD3) xenograft proof-of-concept model was developed to study the efficacies of STX2171 and a more established 17 $\beta$-HSD3 inhibitor, STX1383 (SCH-451659, Schering-Plough), in vivo. Castrated male MF-1 mice were inoculated s.c. with $1 \times 10^{7}$ cells $24 \mathrm{~h}$ after an initial daily dose of testosterone propionate (TP) or vehicle. After 4 weeks, tumours had not developed in vehicle-dosed mice, but were present in $50 \%$ of those mice given TP. One week after switching the stimulus to adione, mice were dosed additionally with the vehicle or inhibitor for a further 4 weeks. Both TP and adione efficiently stimulated tumour growth and increased plasma testosterone levels; however, in the presence of either $17 \beta$-HSD3 inhibitor, adione-dependent tumour growth was significantly inhibited and plasma testosterone levels reduced. Mouse body weights were unaffected. Both inhibitors also significantly lowered plasma testosterone levels in intact mice. In conclusion, STX2171 and STX1383 significantly lower plasma testosterone levels and inhibit androgen-dependent tumour growth in vivo, indicating that $17 \beta-$ HSD3 inhibitors may have application in the treatment of hormone-dependent prostate cancer.
\end{abstract}

Key Words

- prostate

- cancer

- androgen

- 17 $\beta$-hydroxysteroid dehydrogenase (17 $\beta-H S D)$

- inhibition http://erc.endocrinology-journals.org DOI: 10.1530/ERC-12-0231
() 2013 Society for Endocrinology Printed in Great Britain
Published by Bioscientifica Ltd
Endocrine-Related Cancer (2013) 20, 53-64 


\section{Introduction}

Treatment of hormone-dependent prostate cancer by androgen ablation is usually initially successful, reducing primary tumour burden and increasing 5-year survival rates. Currently, androgen ablation is achieved using orchidectomy, androgen receptor (AR) blockers, LH-releasing hormone agonists or $5 \alpha$-reductase inhibitors. Despite the success of these early-stage treatments, prostate cancer is the second highest cause of male cancer-related death in the UK, as tumours often present at an advanced, apparently androgen-independent, stage in older men, having gone unnoticed for several years. However, studies now indicate that almost all advanced prostate cancers are not androgen-independent, and, instead, have developed apparent independence via changes in AR signalling, such as AR up-regulation or mutation, or co-regulator modification, allowing activation by either the low levels of androgen present during ablation therapy or other ligand (Mizokami et al. 2004, Rau et al. 2005, Pienta \& Bradley 2006). High levels of testosterone and $5 \alpha$-dihydrotestosterone (DHT) have been found in the prostate of patients with recurrence during ablation therapy, suggesting that surgical or chemical castration treatments may not completely inhibit androgen formation, and that in situ testosterone formation from adrenal androgens may continue (Titus et al. 2005).

$17 \beta$-Hydroxysteroid dehydrogenases (17 $\beta$-HSDs) catalyse the reduction or oxidation of hormones, fatty acids and bile acids, regulating their binding activities. Fifteen $17 \beta$-HSDs have been identified to date (Jansson et al. 2006, Lukacik et al. 2006, Luu-The et al. 2008), all requiring $\mathrm{NAD}(\mathrm{P})(\mathrm{H})$ for activity (Shi \& Lin 2004). All but one, 17 $\beta$-HSD type 5 (17 $\beta$-HSD5), an aldo-keto reductase (Penning et al. 2000), are short-chain dehydrogenases/ reductases (Peltoketo et al. 1999, Duax et al. 2005, Vihko et al. 2006). In vivo, the 17ß-HSDs appear to function unidirectionally (Luu-The et al. 1995, Khan et al. 2004), despite having bidirectional capabilities in vitro, dependent on $\mathrm{NAD}(\mathrm{P})^{+}$or $\mathrm{NAD}(\mathrm{P}) \mathrm{H}$ availability.

$17 \beta$-HSD3 specifically converts the weakly androgenic adione (Laplante \& Poirier 2008) to active circulating testosterone (Fig. 1) in the presence of NADPH. The importance of $17 \beta-H S D 3$ in testosterone production in men is exemplified by the autosomal recessive disorder male pseudohermaphroditism, where there is defective 17ß-HSD3 expression (Geissler et al. 1994). Affected individuals have a high plasma adione-to-testosterone ratio and are usually brought up as females (Andersson \& Moghrabi 1997).

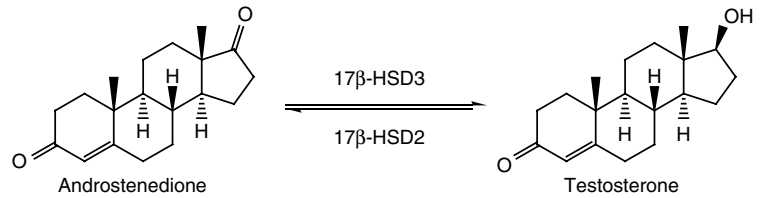

Figure 1

Interconversion of adione and testosterone by $17 \beta-$ HSD3 and $17 \beta-H S D 2$.

Although 17 $\beta$-HSD3 is expressed almost exclusively in testis microsomes (Geissler et al. 1994, Luu-The et al. 1995), there have been some reports of its expression in other tissues, such as blood platelets and megakaryocytes (Gnatenko et al. 2005), and its up-regulation in tumours of the prostate. Expression of $17 \beta$-HSD3 mRNA increased over 30-fold in prostate tumour biopsies in one report (Koh et al. 2002), with a corresponding decrease in $17 \beta$-HSD2 mRNA expression, indicating that the reductive formation of testosterone is favoured, and was up-regulated in an AR-positive prostate cell line, LNCaP, after a 48-h treatment with dutasteride (Biancolella et al. 2007), a $5 \alpha$-reductase 1 and 2 inhibitor. An increased risk of prostate cancer is conferred by a polymorphism in the HSD17B3 gene (Margiotti et al. 2002).

Decreasing the formation of testosterone by the inhibition of $17 \beta$-HSD3 should provide an effective treatment for hormone-dependent prostate cancer. Hormonal treatments acting upstream of the $17 \beta$-HSD3-catalysed reaction can affect the systemic balance of other hormones, causing undesirable adverse effects including loss of sexual interest, function and bone mineral density. However, because of its unique expression profile and substrate specificity, use of 17ß-HSD3 inhibitors may result in fewer side effects (Day et al. 2008b). Furthermore, in castrateresistant prostate cancer (CRPC), de novo androgen synthesis plays a key role in LNCaP xenograft growth (Locke et al. 2008), and human CRPC exhibits up-regulated 17ß-HSD3 expression compared with hormone-resistant prostate cancer (Montgomery et al. 2008).

STX2171 is a 17ß-HSD3 inhibitor with an $\mathrm{IC}_{50}$ of $\sim 200 \mathrm{nM}$ in a whole-cell assay (Day et al. 2009b, Vicker et al. 2009). In vitro, it has been shown to be selective for $17 \beta$-HSD3 over $17 \beta$-HSD2 inhibition, nonandrogenic with low toxicity and to inhibit adionestimulated proliferation of prostate cancer cells in vitro that overexpress $17 \beta$-HSD3. Here, we show that it also has efficacy in vivo, both in the inhibition of testosterone formation in intact male mice, and in a

Published by Bioscientifica Ltd. 
novel adione-stimulated castrated nude mouse prostate cancer xenograft model, inhibiting both tumour growth and plasma testosterone levels.

\section{Materials and methods}

\section{Candidate 17 $\beta$-HSD3 inhibitor compounds}

STX2171 synthesis has been reported (Vicker et al. 2009). Its purity (>95\%) was confirmed by HPLC. STX1383, previously identified by Schering-Plough (Kenilworth, NJ, USA) as a potential 17 $\beta$-HSD3 inhibitor (SCH-451659, Guzi et al. 2004), was synthesised as described previously. The structures of STX2171 and STX1383 are shown in Fig. 2A.

\section{Cell culture}

LNCaP, T47D, MDA-MB-231 and MLTC-1 cells (LGC Promochem, London, UK) were all cultured in RPMI-1640 medium supplemented with 10\% fetal bovine serum (FBS), $2 \mathrm{mM}$ L-glutamine, $1 \%$ non-essential amino acids and 0.075\% sodium bicarbonate (all from Sigma-Aldrich Company Ltd.). PC-3 cells (LGC Promochem) were grown in DMEM/Ham's F12 medium (Sigma-Aldrich Company

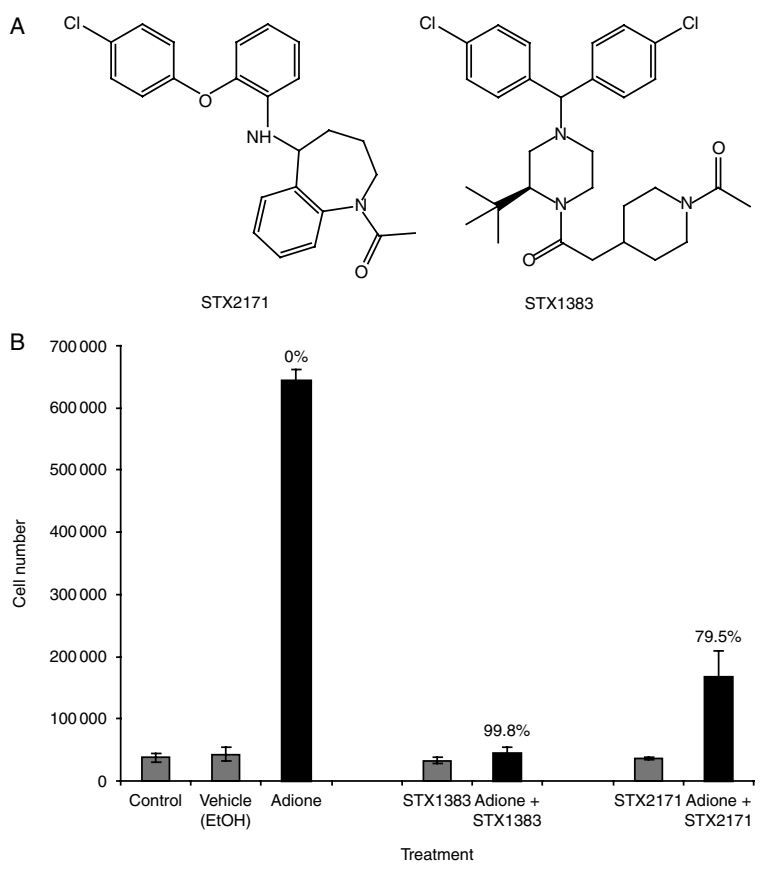

Figure 2

$17 \beta-H S D 3$ inhibitors and their effects in the in vitro proof-of-concept model. (A) Structures of STX2171 and STX1383. (B) Effects of $500 \mathrm{nM}$ STX1383 or STX2171 in the 15-day $10 \mathrm{nM}$ adione-stimulated LNCaP(HSD3) in vitro proof-of-concept assay.

(C) 2013 Society for Endocrinology Printed in Great Britain
Ltd.) supplemented with 10\% FBS and $2 \mathrm{mM}$ L-glutamine. 293-EBNA (Invitrogen Ltd) and LNCaP cells which had been previously transfected and selected for stable expression of the pCEP4.17 $\beta$-HSD3 plasmid (Day et al. 2009b), 293-EBNA(HSD3) and LNCaP(HSD3), respectively, were cultured in the LNCaP medium above, and in DMEM medium supplemented with 10\% FBS, $2 \mathrm{mM}$ L-glutamine, $0.075 \%$ sodium bicarbonate and $250 \mu \mathrm{g} / \mathrm{ml}$ of $\mathrm{G} 418$ (Promega) respectively. Both media were additionally supplemented with $250 \mu \mathrm{g} / \mathrm{ml}$ of hygromycin B (Invitrogen) to maintain the selection of the transfected cells. All cells were maintained at $37^{\circ} \mathrm{C}$ in a humidified atmosphere at $5 \% \mathrm{CO}_{2}$.

\section{$17 \beta$-HSD activity assays}

For the 17 $\beta$-HSD3 assay, 293-EBNA(HSD3) cells and MLTC-1 mouse Leydig tumour cells were plated at 50000 cells/well in 24-well tissue culture plates in medium free of the antibiotics G418 or hygromycin B $48 \mathrm{~h}$ before the assay. The activity of the cells in the presence or absence of STX2171 and STX1383 was determined as described previously (Day et al. 2009b), and the inhibitory $\mathrm{IC}_{50}$ values determined.

The $17 \beta$-HSD1 and 17 $\beta$-HSD2 inhibitory activities of the two compounds were determined using T47D and MDA-MB-231 human breast cancer cells, respectively, as described previously (Day et al. 2009b).

\section{Proliferation assay}

The growth inhibitory IC $_{50}$ for STX1383 and STX2171 in LNCaPwt and PC-3 prostate cancer cells plated at a density of 3500 cells/well was determined as described previously (Stengel et al. 2010). A known anti-proliferative compound, STX140 (Leese et al. 2006, Day et al. 2009a), was included in the assay as a positive control. All experiments were performed in triplicate.

\section{RT-PCR analysis}

Cells in T75 flasks or six-well plates at $\sim 80 \%$ confluency were homogenised using the QIAshredder kit (Qiagen); and excised tumour tissue samples $(30 \mathrm{mg}$ ) were homogenised in $600 \mu \mathrm{l}$ RNeasy RLT buffer (Qiagen) and centrifuged for 3 min at $3000 \boldsymbol{g}$ mRNA was purified using the RNeasy kit (Qiagen) and stored at $-80^{\circ} \mathrm{C}$. cDNA was formed from a $2 \mu \mathrm{g}$ aliquot of each mRNA sample using the High Capacity cDNA RT kit (Applied Biosystems) and stored at $-20^{\circ} \mathrm{C}$. RT-PCRs were performed in a Rotor Gene 2000 Real-Time Cycler (Corbett Life Science, Sydney,

Published by Bioscientifica Ltd 
Australia) using $1 \mu \mathrm{l}$ cDNA in Taqman universal PCR master mix and Taqman expression assays containing primers and probes for $17 \beta-H S D 3$ or AR, and for the endogenous control gene, RPLPO (Applied Biosystems). The conditions were as follows: $95^{\circ} \mathrm{C}$ for $10 \mathrm{~min}$, followed by 40 cycles of $95^{\circ} \mathrm{C}$ for $15 \mathrm{~s}$, and $60^{\circ} \mathrm{C}$ for $60 \mathrm{~s}$. Relative mRNA expression was calculated using the comparative quantitation algorithm in Rotor Gene 6 Software (Corbett Life Science).

\section{In vitro adione-stimulated model}

The effect of the compounds on the adione-stimulated proliferation of LNCaP(HSD3) cells was determined as described previously (Day et al. 2009b).

\section{In vivo studies}

All animals received food and water ad libitum and were maintained in positive pressure isolators under a $12 \mathrm{~h}$ light:12 h darkness cycle. The experiments were approved by the Imperial College London Ethical Review Committee and comply with UK Home Office regulations.

Establishing an in vivo proof-of-concept model: inhibition of adione-stimulated LNCaP(HSD3) tumour proliferation in castrated mice Castrated male MF-1 nude mice (Harlan UK Ltd., Wyton, Cambridgeshire, UK) were inoculated s.c. with $1 \times 10^{7} \mathrm{LNCaP}(\mathrm{HSD} 3)$ cells in $50 \mu \mathrm{l}$ Matrigel (BD Biosciences, Oxford, UK) into one flank $24 \mathrm{~h}$ after an initial daily dose of either $100 \mu \mathrm{g} / 50 \mu \mathrm{l}$ testosterone propionate (TP) in $4 \%$ ethanol/96\% propylene glycol (PG) (s.c.) or vehicle alone. When tumours treated with TP were $50-100 \mathrm{~mm}^{3}$, the tumour-bearing TP-dosed animals were separated into four groups, and animals in group 1 continued on the daily $100 \mu \mathrm{g} / 50 \mu \mathrm{l}$ TP dosing regimen for the remainder of the study, while TP dosing was discontinued in the other three groups. For the following week, these three groups were instead given $100 \mu \mathrm{g}$ adione $/ 50 \mu \mathrm{l}$ vehicle (s.c. daily). After this week, group 2 continued to receive the daily $100 \mu \mathrm{g}$ adione/50 $\mu \mathrm{l}$ vehicle (s.c.) dosing regimen, whereas group 3 received vehicle alone (s.c. daily), and group 4 received $100 \mu \mathrm{g}$ adione $/ 50 \mu \mathrm{l}$ vehicle plus $20 \mathrm{mg} / \mathrm{kg}$ per day STX2171 in a combined s.c. injection ( $n=6-7$ per group). A schematic of the dosing protocol is shown in Fig. 3A. Every 7 days, tumour measurements were recorded using electronic callipers and mice were weighed. Tumour volume was calculated using the formula: volume $=\left(\right.$ length $\times$ width $\left.^{2}\right) / 2$. After 4 further weeks, final body weights and tumour sizes were determined, blood was taken by cardiac puncture $1-2 \mathrm{~h}$ after administration of the final dose; mice were culled and tumour samples were taken.

Comparative efficacy of STX2171 and STX1383 in the in vivo proof-of-concept model LNCaP(HSD3) xenografts were established in castrated male MF-1 mice using TP as above. When tumours measured $50-100 \mathrm{~mm}^{3}$, mice received $100 \mu \mathrm{g}$ adione $/ 50 \mu \mathrm{l}$ vehicle (s.c. daily) for 1 week. For the following 5 weeks, group 1 continued to receive adione, group 2 received adione plus $20 \mathrm{mg} / \mathrm{kg}$ per day STX2171 (s.c.) and group 3 received adione plus $20 \mathrm{mg} / \mathrm{kg}$ per day STX1383 (s.c.) ( $n=6-7$ per group). Tumour measurements and mouse weights were recorded weekly. After 5 weeks, final body weights and tumour sizes were determined, blood was taken by cardiac puncture 1-2 $\mathrm{h}$ after administration of the final dose; mice were culled and tumour samples taken.

Intact mouse study In a 12-day study, intact male MF-1 nude mice (Harlan UK Ltd.) were dosed with vehicle, or with $20 \mathrm{mg} / \mathrm{kg}$ per day STX2171 or STX1383 in $4 \%$ ethanol/96\% PG s.c. daily ( $n=5$ per group) on days $1-5$ and 8-12. On day $12,1 \mathrm{~h}$ after administration of the final dose, blood samples were taken and the animals were culled.

Plasma testosterone concentration Cardiac puncture blood was collected into heparinised tubes and centrifuged at 13000 r.p.m. for $1 \mathrm{~min}$. Plasma was stored at $-20{ }^{\circ} \mathrm{C}$ until assay. Testosterone levels were measured using the Active Testosterone coated-tube RIA ${ }^{125}$ I kit (DSL-4000, Beckman Coulter, High Wycombe, Buckinghamshire, UK), according to the manufacturer's instructions $(50 \mu \mathrm{l}$ sample/assay).

\section{Statistical analyses}

Values obtained in vitro are represented as mean \pm s.D., and those obtained from in vivo studies as mean \pm s.E.M. ANOVA, with a Bonferroni's post-test, was used to determine the significance of differences in in vivo tumour data, and Student's $t$-test was used to determine the significance of differences in plasma testosterone data.

\section{Results}

In vitro analysis of $17 \beta-\mathrm{HSD} 3$ inhibitors

Inhibition of 17 $\beta$-HSD activity STX 2171 had an $\mathrm{IC}_{50}$ value of $208 \mathrm{nM}$ in the whole-cell 293-EBNA(HSD3) radiometric TLC-based assay (Day et al. 2009b). In similar

Published by Bioscientifica Ltd. 


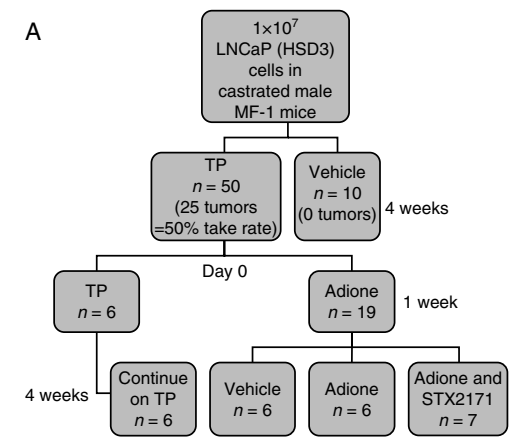

B
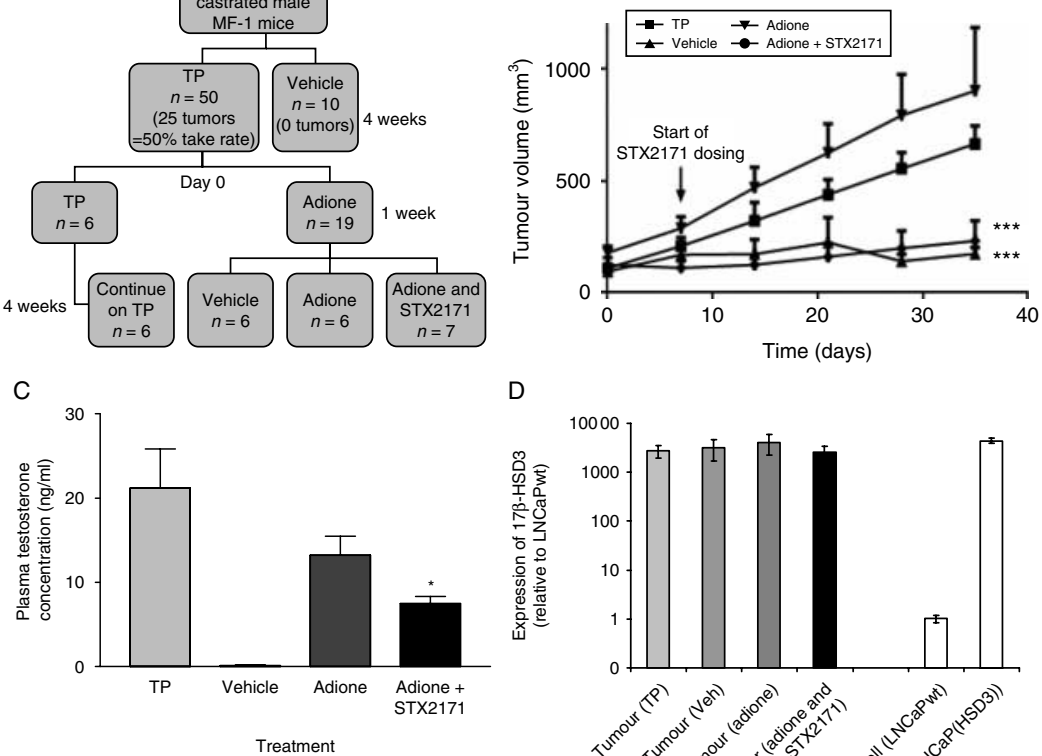

$\mathrm{D}$

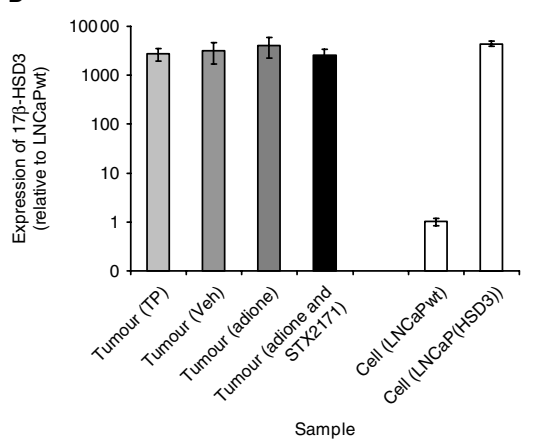

Figure 3

Development of the in vivo proof-of-concept model and the effect of STX2171. (A) Dosing schedule of mice in this study. Mice were treated with either TP or vehicle for 4 weeks. After 4 weeks, $50 \%$ of those dosed with TP developed tumours, whereas none developed tumours in the vehicledosed group. These mice were removed from the study. TP dosing was continued for six mice for the rest of the study, whereas the other 19 were dosed with adione for 1 week, and then separated into three dosing groups and treated with vehicle, adione or adione plus STX2171 for a

$17 \beta$-HSD1 and $17 \beta$-HSD2 activity and inhibition assays (Table 1), STX2171 had negligible activity against the oxidative $17 \beta$-HSD2 enzyme that catalyses the reverse reaction, testosterone to adione (inhibiting 17 $\beta$-HSD2 activity at $10 \mu \mathrm{M}$ by $20.3 \pm 3.5 \%$ ), and was inactive against $17 \beta$-HSD1, the enzyme that catalyses the reduction of the inactive oestrogen $\mathrm{E} 1$ to active $\mathrm{E} 2(1.7 \pm 2.6 \%$ inhibition at $10 \mu \mathrm{M})$.

STX1383, a 17ß-HSD3 inhibitory compound identified by Schering-Plough (Guzi et al. 2004), had an $\mathrm{IC}_{50}$ value of $2.4 \mathrm{nM}$ in the $17 \beta-\mathrm{HSD} 3$ radiometric assay, and was also selective for $17 \beta$-HSD3 over $17 \beta$-HSD2 and $17 \beta$-HSD1, inhibiting these enzymes by only $19.6 \pm 8.8 \%$ at $1 \mu \mathrm{M}$ and $18.4 \pm 4.3 \%$ at $10 \mu \mathrm{M}$ respectively (Table 1 ).

Schering-Plough had previously indicated that STX1383 is active against the mouse $17 \beta$-HSD3 enzyme. In a mouse Leydig tumour cell line, MLTC-1, STX2171 inhibited $17 \beta$-HSD3 activity by $76 \%$ at $1 \mu \mathrm{M}$.

further 4 weeks. (B) Effect of dosing with TP, vehicle or adione \pm STX2171 on tumour growth over the last 5 weeks of the study (mean \pm s.E.M.; $n=6-7$; $* * * P<0.001)$. (C) Plasma testosterone concentration $(\mathrm{ng} / \mathrm{ml}) 1 \mathrm{~h}$ after administration of the final dose of TP, vehicle or adione \pm STX2171 (mean \pm s.E.M.; $n=4-7 ; * P<0.05$ ). (D) Expression of $17 \beta$-HSD3 mRNA in wild-type LNCaP cells (LNCaPwt), in the LNCaP(HSD3) cell line inoculated into the animals and in the tumours of mice at the end of the study (mean \pm s.D.).

Proliferation assay The AR-positive LNCaPwt prostate cancer cell line and an AR-negative prostate cancer cell line, PC-3, were treated with STX1383 and STX2171 over $96 \mathrm{~h}$ to establish cytotoxic effects, unrelated to their $17 \beta$-HSD3 inhibitory activity, on prostate cancer cells. The IC $_{50}$ for growth inhibition by STX2171 was $\sim 100$-fold that for $17 \beta$-HSD3 inhibition, at 16.6 and $23.5 \mu \mathrm{M}$ in LNCaP and PC-3 cells respectively. Although STX1383 was more toxic, with an $\mathrm{IC}_{50}$ for growth inhibition of $5.9 \mu \mathrm{M}$ in LNCaP cells, and $5.8 \mu \mathrm{M}$ in PC-3 cells, this $\mathrm{IC}_{50}$ value was more than 1000 -fold that for $17 \beta$-HSD3 inhibition by this compound (Table 1).

In vitro proof-of-concept model In an in vitro proofof-concept model (Fig. 2B), $10 \mathrm{nM}$ adione stimulated the proliferation of LNCaP(HSD3) cells over 15 days to $\sim 1500 \%$ of the number in $0.1 \%$ FBS medium alone. In the presence of $500 \mathrm{nM}$ STX2171 and STX1383, adionestimulated proliferation was inhibited by 79.5 and $99.8 \%$

Published by Bioscientifica Ltd 
Table 1 Properties of STX1383 and STX2171 in vitro.

\begin{tabular}{|c|c|c|}
\hline Property/compound & STX1383 & STX2171 \\
\hline Human $17 \beta-H S D 3$ inhibition $\left(\mathrm{IC}_{50}(\mathrm{nM})\right)$ & $2.4 \pm 0.6$ & $208 \pm 1$ \\
\hline $17 \beta-\mathrm{HSD} 2$ inhibition $(\%$ at $10 \mu \mathrm{M})$ & $18 . \overline{4} \pm 4.3$ & $20.3 \pm 3.5$ \\
\hline $17 \beta$-HSD 1 inhibition ( $\%$ at $1 \mu \mathrm{M})$ & $19.6 \pm 8.8$ & $1.7 \pm 2.6$ \\
\hline \multicolumn{3}{|l|}{ Cytotoxicity $\left(I C_{50}(\mu \mathrm{M})\right)$} \\
\hline LNCaP $(A R+)$ & 5 & 15.7 \\
\hline $\mathrm{PC}-3(\mathrm{AR}-)$ & 6.8 & 22.0 \\
\hline
\end{tabular}

respectively. Neither of the compounds stimulated or inhibited the proliferation of the cells in the absence of adione.

\section{Inhibition of adione-stimulated LNCaP(HSD3) tumour growth in castrated nude mice}

A schematic diagram showing the treatment regimens for mice is shown in Fig. 3A and further explained in the Materials and methods section.

Although there was little tumour growth in mice dosed with vehicle alone $\left(171.3 \pm 29.0 \mathrm{~mm}^{3}\right.$, most growth occurring during the initial week of TP dosing), the tumours stimulated with either TP or adione grew to 665.3 $\pm 81.3 \mathrm{~mm}^{3}$ by day 35 (TP, $665.3 \pm 81.3 \mathrm{~mm}^{3}$; adione, $903.3 \pm 284.0 \mathrm{~mm}^{3} ; P<0.001$; Fig. 3B). This indicates that, as seen in vitro, $17 \beta$-HSD3 expressed in the LNCaP(HSD3) cells efficiently converted adione to testosterone in mice, stimulating tumour growth. However, in animals given a combined dose of adione plus STX2171, tumour growth was significantly inhibited $\left(229.4 \pm 91.2 \mathrm{~mm}^{3}\right.$ at day 35 ; $P<0.001)$ to the level of those dosed with vehicle alone, indicating that STX2171 inhibited androgen stimulation of tumour growth completely at this dose.

Blood was obtained from four of the six animals in each of the vehicle-, TP- and adione-dosed groups, and from all seven of the adione plus STX2171-dosed group $1 \mathrm{~h}$ after final dose administration, and plasma testosterone concentration was measured by RIA (Fig. 3C). Castrated mice dosed with vehicle alone demonstrated a negligible measurable plasma testosterone $(0.1 \pm 0.1 \mathrm{ng} / \mathrm{ml})$, but mice given TP or adione had plasma concentrations of $21.2 \pm 4.6$ and $13.2 \pm 2.3 \mathrm{ng} / \mathrm{ml}$ respectively. In the adione plus STX2171-dosed group, serum concentration of testosterone was significantly decreased to $7.5 \pm 0.8 \mathrm{ng} / \mathrm{ml}$ $(P<0.05)$ compared with those dosed with adione alone.

RT-PCR analysis indicated that $17 \beta-H S D 3$ mRNA expression in the established LNCaP(HSD3) tumours was unaffected by any treatment, remaining at the level seen in the LNCaP(HSD3) cell line in vitro (Fig. 3D). Xenograft tumour $17 \beta$-HSD3 expression was maintained throughout the study period. Additionally, AR expression was unchanged in tumour samples and mouse body weight was unaffected by treatment (data not shown).

\section{Comparison of the efficacy of STX2171 and STX1383 in the in vivo proof-of-concept tumour model}

This novel in vivo proof-of-concept model was used to compare the efficacy of STX2171 and STX1383 in adionedependent tumours. In mice dosed with adione alone, tumours grew to $592.5 \pm 161.7 \mathrm{~mm}^{3}$ by day 35 (the start of $17 \beta$-HSD3 inhibitor dosing), whereas in those dosed with adione plus STX2171 or STX1383, the final tumour volumes were significantly lower $(P<0.05)$ at $283.3 \pm 53.2$ and $326.2 \pm 73.0 \mathrm{~mm}^{3}$ by day 35 respectively (Fig. 4 A).

Blood hormone concentrations were determined from all mouse groups at the end of the study (Fig. 4B). Plasma testosterone concentration was $14.8 \pm 2.7 \mathrm{ng} / \mathrm{ml}$ in mice dosed with adione alone, but was significantly decreased in both the 17 $\beta$-HSD3 inhibitor-dosed groups: at 6.6 $\pm 1.0 \mathrm{ng} / \mathrm{ml}$ in those dosed with adione plus STX2171 $(P<0.05)$ and at $4.8 \pm 1.0 \mathrm{ng} / \mathrm{ml}$ in animals dosed with adione plus STX1383 $(P<0.01)$.

As in the previous study, RT-PCR analysis indicated that $17 \beta$-HSD3 (Fig. 4C) and AR mRNA expression (results not shown) in the LNCaP(HSD3) tumours were unaffected by any treatment, remaining at the levels seen in the LNCaP(HSD3) cell line in vitro. Additionally, mouse body weight was unaffected by any of the treatments (Fig. 4D), demonstrating that STX2171 and STX1383 do not have significant toxicological problems when dosed at $20 \mathrm{mg} / \mathrm{kg}$ per day.

\section{Intact mouse study}

As an initial simple in vivo screen, an intact mouse model of $17 \beta$-HSD3 inhibition was established. However, this model relies on the inhibition of the mouse 17 $\beta$-HSD3 enzyme, rather than that of the human enzyme as in the tumour model.

At the end of a 12-day study, in which intact male MF-1 nude mice were given daily doses of either $20 \mathrm{mg} / \mathrm{kg}$ per day STX2171 or STX1383 (s.c.) on days 1-5 and 8-12, plasma testosterone concentration was significantly decreased in both dosing groups $(P<0.05 ; n=5$ per group; Fig. 5$)$. In mice dosed with STX2171, plasma testosterone concentration decreased to $0.41 \pm 0.09 \mathrm{ng} / \mathrm{ml}, 11.2 \%$ of that of the control $(3.65 \pm 2.45 \mathrm{ng} / \mathrm{ml})$, and in the STX1383-dosed animals, the concentration was $0.63 \pm 0.20 \mathrm{ng} / \mathrm{ml}, 17.4 \%$ of that measured in control vehicle-dosed mice.

Published by Bioscientifica Ltd. 
A

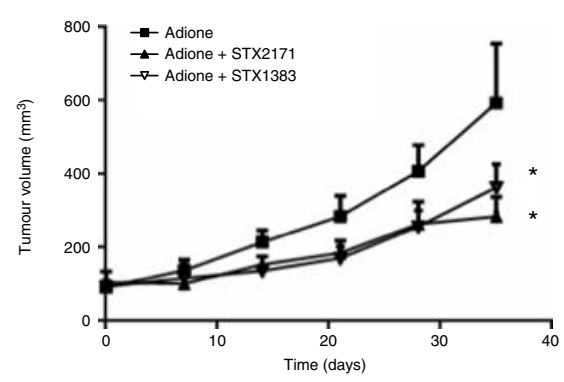

C

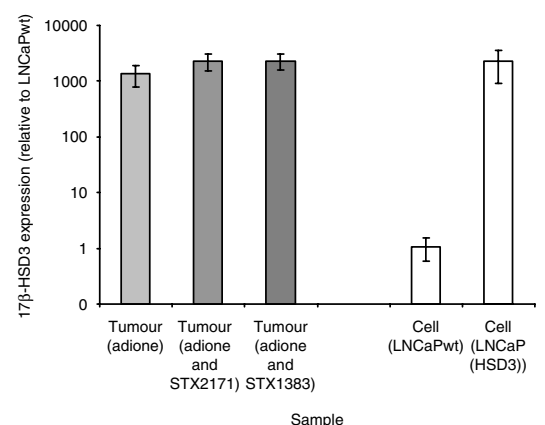

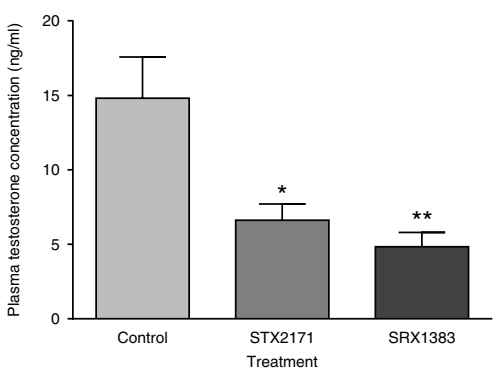

D

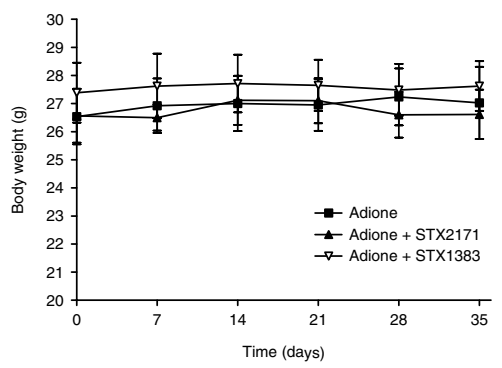

Figure 4

Effects of the 17 $\beta$-HSD3 inhibitors in the in vivo proof-of-concept model. (A) The effect of dosing with adione \pm STX2171 or STX1383 on tumour growth (mean \pm s.E.M.; $n=6-8 ; * P<0.05$ ). (B) Plasma testosterone concentration $(\mathrm{ng} / \mathrm{ml}) 1 \mathrm{~h}$ after administration of the final dose of adione \pm STX2171 or STX1383 (mean \pm s.E.M.; $n=6-7 ; * P<0.05$ and $* * P<0.01$ ).

\section{Discussion}

Inhibitors of several steroidogenic enzymes are successfully used to treat hormone-dependent cancers in the clinic. These include, for use in early-stage prostate cancer and in benign prostate hyperplasia (BPH), $5 \alpha$-reductase inhibitors such as finasteride and dutasteride, and in ER-positive breast cancer, aromatase and steroid sulfatase inhibitors (Stanway et al. 2007). However, contrastingly, the development of $17 \beta$-HSD inhibitors is at a relatively early stage (Day et al. 2010). At present, none of these inhibitors has reached clinical trial, and only recently has efficacy been demonstrated in vivo for inhibitors of the first of the enzymes, $17 \beta$-HSD1, in models of breast cancer (Day et al. 2006, 2008a, Husen et al. 2006) and endometrial hyperplasia (Saloniemi et al. 2010). 17 $\beta$-HSD3 catalyses the reduction of adione to form testosterone, further metabolised by $5 \alpha$-reductases to DHT, which stimulates the growth of hormone-dependent prostate tumours. This report describes the development of in vivo models to investigate the efficacy of $17 \beta$-HSD3 inhibitors as therapies for androgen-dependent prostate cancer.
(C) Expression of 17 $\beta$-HSD3 mRNA in wild-type LNCaP cells (LNCaPwt), in the LNCaP(HSD3) cell line inoculated into the animals, and in the tumours of mice at the end of the study (mean \pm s.D.). (D) Effect of the dosing on mouse body weight (mean \pm S.E.M.; $n=6-8$; NS, $P>0.05$ ).

Previously, we described the development of in vitro assays and models to investigate the use of compounds as inhibitors of $17 \beta$-HSD3 (Day et al. 2009b). As the expression of $17 \beta-\mathrm{HSD} 3$ and $17 \beta-\mathrm{HSD} 2$ was found to be negligible in AR-positive LNCaPwt prostate cancer cells, a stable $17 \beta$-HSD3-expressing cell line was selected for after transfection with pCEP4.17 $\beta$-HSD3. This cell line, LNCaP(HSD3), provided a good model in which to study the effects of $17 \beta$-HSD3 inhibition in prostate cancer cells, especially as LNCaP cells are known to be responsive to androgenic stimuli, both in vitro and in vivo (Horoszewicz et al. 1983). In the present study, we have taken this adione-stimulated model from the in vitro to the in vivo setting, stimulating growth of the cells as androgenstimulated LNCaP(HSD3) xenografts in castrated nude mice. Additionally, we have set up a simpler, faster in vivo assay as an initial in vivo screen for candidate $17 \beta$-HSD3 inhibitors that relies on the endogenous $17 \beta$-HSD3 present in intact mice.

STX2171 was previously identified as the most active of a panel of 50 compounds designed as 17 $\beta$-HSD3

Published by Bioscientifica Ltd 


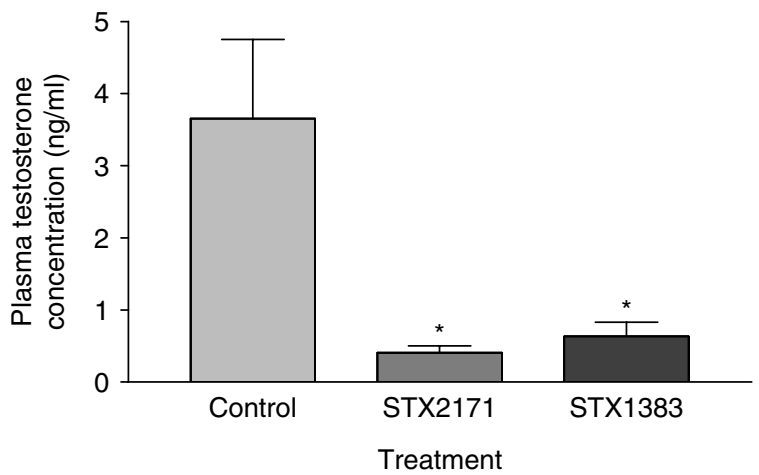

Figure 5

Inhibition of testosterone formation by $17 \beta$-HSD3 inhibitors in intact male mice in vivo. Plasma testosterone concentrations $(\mathrm{ng} / \mathrm{ml})$ in intact male MF-1 nude mice $1 \mathrm{~h}$ after administration of the final dose of STX2171 or STX1383 in a 12-day study (mean \pm S.E.M.; $n=5 ; * P<0.05$ ).

inhibitors (Vicker et al. 2009), with an $\mathrm{IC}_{50}$ of $208 \mathrm{nM}$ in our whole-cell assay. STX1383, which in our assay inhibits $17 \beta$-HSD3 with an $\mathrm{IC}_{50}$ of $2.4 \mathrm{nM}$, was originally synthesised by Schering-Plough as SCH-451659 (Guzi et al. 2004). In this study, we have used STX2171 to develop the in vivo models, and have compared its efficacy with that of STX1383 in vivo.

Initially, compounds were investigated in vitro. Although the $\mathrm{IC}_{50}$ of STX1383 was $~ 100$-fold lower than that of STX2171, both compounds were similarly inactive against $17 \beta$-HSD1. STX2171 had negligible activity $(20.3 \%$ at $10 \mu \mathrm{M})$ against the inactivating enzyme $17 \beta-H S D 2$, whereas STX1383 had slightly more activity $(19.6 \%$ at $1 \mu \mathrm{M})$. However, as it has 100-fold higher 17 $\beta$-HSD3 inhibitory activity in vitro than STX2171, its selectivity for $17 \beta$-HSD3 over $17 \beta$-HSD2 is comparable with that of STX2171.

In both AR-positive and AR-negative prostate cancer cells, the $\mathrm{IC}_{50}$ value for each compound was similar, indicating that neither compound has any pro- or antiandrogenic effects. Although the anti-proliferative $\mathrm{IC}_{50}$ values for STX1383 were around 3.5-fold lower than those of STX2171, indicating STX1383 as slightly more cytotoxic, the values for STX2171 were $\sim 100$-fold higher than its $\mathrm{IC}_{50}$ for $17 \beta$-HSD3 inhibition, and those for STX1383 were $>2000$-fold, suggesting that both compounds have negligible toxicity at the doses required for $17 \beta$-HSD3 inhibition. In the in vitro proof-of-concept model, at $500 \mathrm{nM}$, both compounds inhibited adione stimulation of LNCaP(HSD3) cells, with STX1383 demonstrating better activity (99.8\% inhibition), as would be expected from its lower $\mathrm{IC}_{50}$ value for $17 \beta$-HSD3 inhibition. The
79.5\% inhibition seen for STX2171 is comparable with that obtained in a previous similar study (74\%; Day et al. $2009 b)$.

Having previously successfully developed an in vivo breast cancer model of 17ß-HSD1 inhibition (Day et al. $2008 a$ ), we used similar principles to develop the in vivo androgen-stimulated human $17 \beta$-HSD3-dependent prostate tumour model. In the $17 \beta$-HSD1 ovariectomised breast cancer model, wild-type human T47D breast cancer cells stimulated with E1 were used, as they are ER-positive and have a high 17 $\beta$-HSD1:17 $\beta$-HSD2 ratio. Because there is no established AR-positive human prostate cancer cell line expressing a similar ratio of $17 \beta-H S D 3: 17 \beta-H S D 2$, we developed the LNCaP(HSD3) cell line for the prostate model, as LNCaP cells are AR-dependent and have low expression of $17 \beta$-HSD2. Castrated male animals were used so that, when stimulated with adione, the growth of the cells would be dependent on the $17 \beta$-HSD3 activity of the human enzyme expressed by the inoculated LNCaP(HSD3) cells.

Initially, TP was used to establish the growth of the androgen-dependent LNCaP(HSD3) xenografts. Testosterone was administered as its propionate ester due to the short half-life of free testosterone (Mallidis et al. 2012). After 4 weeks, 25 of the 50 mice dosed with TP had developed tumours of $50-100 \mathrm{~mm}^{3}$, but tumours had not developed in any of the ten mice given vehicle alone. This indicated that castration was effective and that tumour growth was androgen-dependent. The animals that had not developed tumours by 4 weeks were removed from the study. The $50 \%$ take rate suggests that this dose of TP is just enough to stimulate the growth of these cells in castrated mice, although similarly low take rates have been documented in other studies in which xenografts have been formed from inoculated transfected LNCaP cells (Russell et al. 1999, Perryman et al. 2006).

Once the tumours had reached $50-100 \mathrm{~mm}^{3}$, the stimulus was switched to adione, and the tumours continued to grow as efficiently as those dosed with TP for the remainder of the study, indicating that $17 \beta$-HSD3 in the tumours efficiently converted the dosed adione to testosterone. Growth was significantly inhibited in the presence of $20 \mathrm{mg} / \mathrm{kg}$ STX2171, to the level of those mice dosed with vehicle alone.

Testosterone concentration in the plasma was significantly lowered in STX2171-treated mice $1 \mathrm{~h}$ after administration of the final dose, to $56.7 \pm 6.3 \%$ of that in the animals dosed with adione alone. The concentration of testosterone in the plasma of those given TP was, however, unexpectedly significantly higher than those

Published by Bioscientifica Ltd 
dosed with adione, given the similar growth rate of the tumours in the two groups. This may be due to the scheduling of the final dose administration of each steroid $1-2 \mathrm{~h}$ before the blood sample was obtained by cardiac puncture. This short duration may not allow for the maximal conversion of the administered adione to testosterone, as would have happened during each $24 \mathrm{~h}$ period throughout the study. Furthermore, it is noted that STX2171 failed to completely inhibit plasma testosterone concentrations despite inhibiting tumour growth. As plasma was collected $1 \mathrm{~h}$ after the final dose of adione and STX2171, testosterone measured may reflect the slower delivery of the compound to the tumour compared with the hormone. Consequently, some adione would be converted by LNCaP $17 \beta$-HSD3 activity. However, we suggest that $17 \beta$-HSD3 inhibition did occur more completely after $1 \mathrm{~h}$, blocking the conversion of remaining adione and hence inhibiting tumour growth.

These results indicated the development of a successful model in which to test clinical candidate 17 $\beta$-HSD3 inhibitors in vivo; we therefore used this model to compare the efficacy of STX2171 and STX1383, the Schering-Plough compound which has a more favourable $17 \beta-H S D 3$ inhibitory $\mathrm{IC}_{50}$ in vitro. STX2171 was again tested at $20 \mathrm{mg} / \mathrm{kg}$ per day, to study the reproducibility of the model, and STX1383 was also given at this dose. Again, administration of adione resulted in the steady growth of the LNCaP(HSD3) tumours, and the growth was significantly inhibited by co-administration of either of the two 17 $\beta$-HSD3 inhibitors tested. In the last 2 weeks of study, although STX2171 maintained its inhibition of tumour growth, the effect of STX1383 appeared to decline; however, the difference between the effects of the two compounds was nonsignificant over this time duration. Inhibition by STX2171, to $39 \%$ of the adione-treated tumour volume, is highly comparable with the results from the first study, in which STX2171-treated tumours inhibited tumour growth to 35\% of that of the adione-dosed animals, indicating that this is a robust, reproducible model. In both studies, RT-PCR analysis indicated that neither the androgens nor the inhibitors affected the expression of the transfected $17 \beta-H S D 3$ or the wild-type AR in the xenografts.

In this study, in plasma samples taken $1-2 \mathrm{~h}$ after administration of the final dose, although both compounds significantly lowered plasma testosterone levels, STX1383 more efficiently reduced plasma testosterone concentrations, to $32 \%$ of those dosed with adione alone, compared with a decrease to $45 \%$ of control in the STX2171-dosed animals; this is a little lower than the $57 \%$ in the first study.
These studies demonstrate the development of a novel, robust in vivo proof-of-concept model for the evaluation of $17 \beta-H S D 3$ inhibitors against androgendependent prostate cancer. However, this model has limitations for high-throughput usage as it is timeconsuming and expensive, requiring more animals than are used in the final dosing phase due to the relatively low take rate of the LNCaP(HSD3) tumours, and additionally requiring castrated animals. Therefore, as an initial screen for in vivo efficacy and inhibitor properties, a simple 12-day intact mouse model was set up. In this model, mice were treated with the $17 \beta-H S D 3$ inhibitors on days $1-5$ and $8-12$, again at $20 \mathrm{mg} / \mathrm{kg}$ per day, and blood samples were taken $1 \mathrm{~h}$ after the final dose, so that the plasma testosterone result scheduling was directly comparable with that of the proof-of-concept tumour model. Both inhibitors significantly inhibited plasma testosterone concentration in this model, to $<20 \%$ of that measured in control mice.

It is important to remember that in this intact mouse model, it is the mouse $17 \beta-H S D 3$ enzyme, and not the human homologue, which is being inhibited (contrary to the proof-of-concept model). The efficacy shown by both inhibitors in the intact mouse model supports the results in mouse Leydig cells in vitro which demonstrated that STX2171 is active against the mouse enzyme. ScheringPlough has previously indicated that STX1383 is active against the mouse enzyme, albeit with an $\mathrm{IC}_{50} \sim 1000$-fold higher than that for the human enzyme (Pachter et al. 2005). Although the clinical relevancy of mouse 17 $\beta$-HSD3 inhibition in this model is questionable, the intact status of mice results in less controlled steroid conditions in vivo, and this may thus be more similar to the steroidogenic state in prostate cancer and BPH patients. Although $17 \beta$-HSD3 expression has been seen to be up-regulated in prostate cancer (Koh et al. 2002), the majority of the $17 \beta$-HSD3 activity in humans is gonadal (Geissler et al. 1994). The mice in this study were dosed for 12 days so that, in addition to the effect on plasma testosterone levels, the effect of the inhibitors on prostate size could be studied. Unfortunately, due to the small size of the mouse prostate, prostate weight could not be measured accurately in these young animals.

Use of these in vivo models indicates that our lead $17 \beta$-HSD3 inhibitor, STX2171, is at least as efficient as the Schering-Plough compound in vivo, both at lowering plasma testosterone levels and at inhibiting the proliferation of androgen-dependent prostate tumours when stimulated by adione. Although several groups are now working on inhibitors of 17 $\beta$-HSD3 (Le Lain et al. 2002,

Published by Bioscientifica Ltd. 
Maltais et al. 2002, Tchédam Ngatcha et al. 2005, Fink et al. 2006, Lota et al. 2006, Berube \& Poirier 2007), this is the first report on anti-tumour activity of a $17 \beta$-HSD3 inhibitor in vivo. Having developed the primary screening assays and an in vitro proof-of-concept model, and selected a lead compound with good activity selective for $17 \beta$-HSD3 over other $17 \beta$-HSD enzymes, non-androgenic with low toxicity, and efficacious in the in vitro proofof-concept model (Day et al. 2009b), we have now developed novel robust models to study the efficacy of this and future candidate compounds in vivo.

Further work on this model and STX2171 is required. Our in vivo studies imply that the majority of adione was converted to testosterone by LNCaP $17 \beta$-HSD3 activity. However, it has recently been suggested that the dominant pathway of adione metabolism in CRPR is through adione conversion to $5 \alpha$-adione via SRD5A (Chang et al. 2011). $5 \alpha$-Adione is then the substrate for $17 \beta$-HSD3 to synthesis DHT. Our studies did not investigate adione-induced DHT plasma concentrations. However, as $17 \beta-H S D 3$ is involved in this alternative pathway for adione metabolism, STX2171 and STX1383 should also inhibit this pathway. This fact makes these compounds significantly more interesting with regard to the treatment of CRPR.

These models provide evidence that $17 \beta-H S D 3$ inhibitory compounds may have application in the treatment of hormone-dependent prostate cancer. STX2171 represents an attractive compound class suitable for further optimisation towards preclinical development, inhibiting the growth of adione-dependent tumours in the in vivo prostate cancer xenograft model and significantly decreasing plasma testosterone concentrations both in this model and in intact mice.

\section{Declaration of interest}

F Schmidlin is an employee of Ipsen. A Purohit is a consultant for Ipsen. BVL Potter \& MJ Reed were consultants for Ipsen.

\section{Funding}

This work was supported by Sterix Ltd., a member of the Ipsen Group.

\section{Author contribution statement}

A Purohit, B V L Potter and M J Reed conceived and coordinated the project and designed experiments with $\mathrm{F}$ Schmidlin. J M Day designed the in vitro experiments, performed both the in vitro proof-of-concept model and the in vivo intact male mouse model, and statistical analysis. P A Foster designed and performed all in vivo experiments, collecting data and statistical analysis. $\mathrm{H} \mathrm{J}$ Tutill helped design the in vitro modelling, ascertained the $\mathrm{IC}_{50}$ values and ran the in vitro proof-of-concept assay.
B V L Potter and N Vicker designed STX2171. C M Sharland and J D Hargrave synthesised STX2171 and STX1383. P A Foster, J M Day \& A Purohit wrote the manuscript with input from all authors.

\section{References}

Andersson S \& Moghrabi N 1997 Physiology and molecular genetics of $17 \beta$-hydroxysteroid dehydrogenases. Steroids 62 143-147. (doi:10.1016/S0039-128X(96)00173-0)

Berube M \& Poirier D 2007 Chemical synthesis and in vitro biological evaluation of a phosphorylated bisubstrate inhibitor of type 3 $17 \beta$-hydroxysteroid dehydrogenase. Journal of Enzyme Inhibition and Medicinal Chemistry 22 201-211. (doi:10.1080/14756360601051423)

Biancolella M, Valentini A, Minella D, Vecchione L, D'Amico F, Chillemi G, Gravina P, Bueno S, Prosperini G, Desideri A et al. 2007 Effects of dutasteride on the expression of genes related to androgen metabolism and related pathway in human prostate cancer cell lines. Investigational New Drugs 25 491-497. (doi:10.1007/s10637-007-9070-7)

Chang KH, Li R, Papri-Zareei M, Watumull 1, Zhao YD, Auchus RJ \& Sharifi N 2011 Dihydrotestosterone synthesis bypasses testosterone to drive castration-resistant prostate cancer. PNAS 108 13728-13733. (doi:10.1073/pnas.1107898108)

Day JM, Foster PA, Chander SK, Tutill HJ, Parsons MFC, Allan GM, Lawrence HR, Vicker N, Potter BVL, Reed MJ \& Purohit A 2006 Inhibition of estrone-dependent tumor growth in vivo by the 17 $\beta$-HSD1 inhibitor, 2-ethyl-16 $\beta$ - $m$-pyridylmethylamidomethyl-estrone (2-EtE1-F). Breast Cancer Research and Treatment 100 S197.

Day JM, Foster PA, Tutill HJ, Parsons MFC, Newman SP, Chander SK, Allan GM, Lawrence HR, Vicker N, Potter BVL et al. 2008a 17 $\beta$ Hydroxysteroid dehydrogenase type 1 , and not type 12 , is a target for endocrine therapy of hormone-dependent breast cancer. International Journal of Cancer 122 1931-1940. (doi:10.1002/ijc.23350)

Day JM, Tutill HJ, Purohit A \& Reed MJ 2008 $b$ Design and validation of specific inhibitors of $17 \beta$-hydroxysteroid dehydrogenases for therapeutic application in breast and prostate cancer, and in endometriosis. Endocrine-Related Cancer 15 665-692. (doi:10.1677/ERC-08-0042)

Day JM, Foster PA, Tutill HJ, Newman SP, Ho YT, Leese MP, Potter BVL, Reed MJ \& Purohit A 2009a BCRP expression does not result in resistance to STX140 in vivo, despite the increased expression of BCRP in A2780 cells in vitro after long-term STX140 exposure. British Journal of Cancer 100 476-486. (doi:10.1038/sj.bjc.6604873)

Day JM, Tutill HJ, Foster PA, Bailey HV, Heaton WB, Sharland CM, Vicker N, Potter BVL, Purohit A \& Reed MJ $2009 b$ Development of hormonedependent prostate cancer models for the evaluation of inhibitors of $17 \beta$-hydroxysteroid dehydrogenase type 3. Molecular and Cellular Endocrinology 301 251-258. (doi:10.1016/j.mce.2008.08.014)

Day JM, Tutill HJ \& Purohit A 2010 17 $\beta$-Hydroxysteroid dehydrogenase inhibitors. Minerva Endocrinologica 35 87-108.

Duax WL, Thomas J, Pletnev V, Addlagatta A, Huether R, Habegger L \& Weeks CM 2005 Determining structure and function of steroid dehydrogenase enzymes by sequence analysis, homology modeling, and rational mutational analysis. Annals of the New York Academy of Sciences 1061 135-148. (doi:10.1196/annals.1336.015)

Fink BE, Gavai AV, Tokarski JS, Goyal B, Misra R, Xiao H-Y, Kimball SD, Han W-C, Norris D, Spires TE et al. 2006 Identification of a novel series of tetrahydrodibenzazocines as inhibitors of $17 \beta$-hydroxysteroid dehydrogenase type 3. Bioorganic \& Medicinal Chemistry Letters 16 1532-1536. (doi:10.1016/j.bmcl.2005.12.039)

Geissler WM, Davis DL, Wu L, Bradshaw KD, Patel S, Mendonca BB, Elliston KO, Wilson JD, Russell DW \& Andersson S 1994 Male pseudohermaphroditism caused by mutations of testicular 17ß-hydroxysteroid dehydrogenase 3. Nature Genetics 7 34-39. (doi:10.1038/ng0594-34)

Gnatenko DV, Cupit LD, Huang EC, Dhundale A, Perrotta PL \& Bahou WF 2005 Platelets express steroidogenic $17 \beta$-hydroxysteroid 
dehydrogenases. Distinct profiles predict the essential thrombocythemic phenotype. Thrombosis and Haemostasis 94 412-421. (doi:10.1160/ TH05-01-0037)

Guzi TJ, Liu Y, Doll RJ, Saksena A, Girijavallabhan VM \& Pachter JA 2004 $17 \beta$-Hydroxysteroid dehydrogenase type 3 inhibitors for the treatment of androgen-dependent diseases. WO 2004/046111 A1.

Horoszewicz JS, Leong SS, Kawinski E, Karr JP, Rosenthal H, Chu TM, Mirand EA \& Murphy GP 1983 LNCaP model of human prostatic carcinoma. Cancer Research 43 1809-1818.

Husen B, Huhtinen K, Poutanen M, Kangas L, Messinger J \& Thole H 2006 Evaluation of inhibitors for $17 \beta$-hydroxysteroid dehydrogenase type 1 in vivo in immunodeficient mice inoculated with MCF-7 cells stably expressing the recombinant human enzyme. Molecular and Cellular Endocrinology 248 109-113. (doi:10.1016/j.mce.2005.11.042)

Jansson AK, Gunnarsson C, Cohen M, Sivik T \& Stal O 2006 $17 \beta$-Hydroxysteroid dehydrogenase 14 affects estradiol levels in breast cancer cells and is a prognostic marker in estrogen receptor-positive breast cancer. Cancer Research 66 11471-11477. (doi:10.1158/00085472.CAN-06-1448)

Khan N, Sharma KK, Andersson S \& Auchus RJ 2004 Human $17 \beta$-hydroxysteroid dehydrogenases types 1,2 , and 3 catalyze bi-directional equilibrium reactions, rather than unidirectional metabolism, in HEK-293 cells. Archives of Biochemistry and Biophysics 429 50-59. (doi:10.1016/j.abb.2004.05.023)

Koh E, Noda T, Kanaya J \& Namiki M 2002 Differential expression of $17 \beta$-hydroxysteroid dehydrogenase isozyme genes in prostate cancer and noncancer tissues. Prostate 53 154-159. (doi:10.1002/pros.10139)

Laplante Y \& Poirier D 2008 Proliferative effect of androst-4-ene-3,17-dione and its metabolites in the androgen-sensitive LNCaP cell line. Steroids 73 266-271. (doi:10.1016/j.steroids.2007.10.009)

Leese MP, Leblond B, Smith A, Newman SP, Di Fiore A, De Simone G, Supuran CT, Purohit A, Reed MJ \& Potter BVL 2006 2-Substituted estradiol bis-sulfamates, multitargeted antitumor agents: synthesis, in vitro SAR, protein crystallography, and in vivo activity. Journal of Medicinal Chemistry 49 7683-7696. (doi:10.1021/jm060705x)

Le Lain R, Barrell KJ, Saeed GS, Nicholls PJ, Simons C, Kirby A \& Smith HJ 2002 Some coumarins and triphenylethene derivatives as inhibitors of human testes microsomal $17 \beta$-hydroxysteroid dehydrogenase (17 $\beta$-HSD type 3): further studies with tamoxifen on the rat testes microsomal enzyme. Journal of Enzyme Inhibition and Medicinal Chemistry 17 93-9100. (doi:10.1080/14756360290026441)

Locke JA, Guns ES, Lubik AA, Adomat HH, Hendy SC, Wood CA, Ettinger SL, Gleave ME \& Nelson CC 2008 Androgen levels increase by intratumoral de novo steroidogenesis during progression of castration-resistant prostate cancer. Cancer Research 68 6407-6415. (doi:10.1158/00085472.CAN-07-5997)

Lota RK, Dhanani S, Owen CP \& Ahmed S 2006 Synthesis, biochemical evaluation and rationalisation of the inhibitory activity of a series of 4-hydroxyphenyl ketones as potential inhibitors of $17 \beta$-hydroxysteroid dehydrogenase type 3 (17 $\beta$-HSD3). Bioorganic \& Medicinal Chemistry Letters 16 4519-4522. (doi:10.1016/j.bmcl.2006.06.029)

Lukacik P, Kavanagh KL \& Oppermann U 2006 Structure and function of human 17ß-hydroxysteroid dehydrogenases. Molecular and Cellular Endocrinology 248 61-71. (doi:10.1016/j.mce.2005.12.007)

Luu-The V, Zhang Y, Poirier D \& Labrie F 1995 Characteristics of human types 1, 2 and $317 \beta$-hydroxysteroid dehydrogenase activities: oxidation/reduction and inhibition. Journal of Steroid Biochemistry and Molecular Biology 55 581-587. (doi:10.1016/0960-0760(95)00209-X)

Luu-The V, Belanger A \& Labrie F 2008 Androgen biosynthetic pathways in the human prostate. Best Practice \& Research. Clinical Endocrinology \& Metabolism 22 207-221. (doi:10.1016/j.beem.2008.01.008)

Mallidis C, Cooper TG, Hellenkemper B, Lablans M, Uckert F \& Nieschlag E 2012 Ten years' experience with an external quality control program for semen analysis. Fertility and Sterility 98 611-616. (doi:10.1016/ j.fertnstert.2012.05.006)
Maltais R, Luu-The V \& Poirier D 2002 Synthesis and optimization of a new family of type $317 \beta$-hydroxysteroid dehydrogenase inhibitors by parallel liquid-phase chemistry. Journal of Medicinal Chemistry $\mathbf{4 5}$ 640-653. (doi:10.1021/jm010286y)

Margiotti K, Kim E, Pearce CL, Spera E, Novelli G \& Reichardt JKV 2002 Association of the G289S single nucleotide polymorphism in the HSD17B3 gene with prostate cancer in Italian men. Prostate 53 65-68. (doi:10.1002/pros.10134)

Mizokami A, Koh E, Fujita H, Maeda Y, Egawa M, Koshida K, Honma S, Keller ET \& Namiki M 2004 The adrenal androgen androstenediol is present in prostate cancer tissue after androgen deprivation therapy and activates mutated androgen receptor. Cancer Research 64 765-771. (doi:10.1158/0008-5472.CAN-03-0130)

Montgomery RB, Mostaghel EA, Vessella R, Hess DL, Kalhorn TF, Higano CS, True LD \& Nelson PS 2008 Maintenance of intratumoral androgens in metastatic prostate cancer: a mechanism for castration-resistant tumor growth. Cancer Research 68 4447-4454. (doi:10.1158/0008-5472. CAN-08-0249)

Pachter JA, Huryk R, Ramos RA, Meredith J, Weinbauer G \& Guzi T 2005 Inhibition of $17 \beta-H S D 3$ as a novel approach to treat androgendependent prostate cancer: efficacy in cynomolgus monkeys. Proceedings of the American Association for Cancer Research 463176.

Peltoketo H, Luu-The V, Simard J \& Adamski J 1999 17 $\beta$-Hydroxysteroid dehydrogenase (HSD)/17-ketosteroid reductase (KSR) family; nomenclature and main characteristics of the 17HSD/KSR enzymes. Journal of Molecular Endocrinology 23 1-11. (doi:10.1677/jme.0.0230001)

Penning TM, Burczynski ME, Jez JM, Hung CF, Lin HK, Ma H, Moore M, Palackal N \& Ratnam K 2000 Human $3 \alpha$-hydroxysteroid dehydrogenase isoforms (AKR1C1-AKR1C4) of the aldo-keto reductase superfamily: functional plasticity and tissue distribution reveals roles in the inactivation and formation of male and female sex hormones. Biochemical Journal 351 67-77. (doi:10.1042/0264-6021:3510067)

Perryman LA, Blair JM, Kingsley EA, Szymanska B, Ow KT, Wen VW, MacKenzie KL, Vermeulen PB, Jackson P \& Russell PJ 2006 Over-expression of p53 mutants in LNCaP cells alters tumor growth and angiogenesis in vivo. Biochemical and Biophysical Research Communications 345 1207-1214. (doi:10.1016/j.bbrc.2006.05.020)

Pienta KJ \& Bradley D 2006 Mechanisms underlying the development of androgen-independent prostate cancer. Clinical Cancer Research $\mathbf{1 2}$ 1665-1671. (doi:10.1158/1078-0432.CCR-06-0067)

Rau KM, Kang HY, Cha TL, Miller SA \& Hung MC 2005 The mechanisms and managements of hormone-therapy resistance in breast and prostate cancers. Endocrine-Related Cancer 12 511-532. (doi:10.1677/ erc.1.01026)

Russell PJ, Bennett S, Joshua A, Yu Y, Downing SR, Hill MA, Kingsley EA, Mason RS \& Berry J 1999 Elevated expression of FGF-2 does not cause prostate cancer progression in LNCaP cells. Prostate 40 1-13. (doi:10. 1002/(SICI) 1097-0045(19990615)40:1 <1::AID-PROS1 > 3.0.CO;2-K)

Saloniemi T, Jarvensivu P, Koskimies P, Jokela H, Lamminen T, GhaemMaghami S, Dina R, Damdimopoulou P, Makela S, Perheentupa A et al. 2010 Novel hydroxysteroid (17 $\beta$ ) dehydrogenase 1 inhibitors reverse estrogen-induced endometrial hyperplasia in transgenic mice. American Journal of Pathology 176 1443-1451. (doi:10.2353/ajpath. 2010.090325)

Shi R \& Lin S-X 2004 Cofactor hydrogen bonding onto the protein main chain is conserved in the short chain dehydrogenase/reductase family and contributes to nicotinamide orientation. Journal of Biological Chemistry 279 16778-16785. (doi:10.1074/jbc.M313156200)

Stanway SJ, Delavault P, Purohit A, Woo LWL, Thurieau C, Potter BVL \& Reed MJ 2007 Steroid sulfatase: a new target for the endocrine therapy of breast cancer. Oncologist 12 370-374. (doi:10.1634/theoncologist. 12-4-370)

Stengel C, Newman SP, Leese MP, Potter BVL, Reed MJ \& Purohit A 2010 Class III $\beta$-tubulin expression and in vitro resistance to microtubule targeting agents. British Journal of Cancer 102 316-324. (doi:10.1038/sj. bjc.6605489) 
Titus MA, Schell MJ, Lih FB, Tomer KB \& Mohler JL 2005 Testosterone and dihydrotestosterone tissue levels in recurrent prostate cancer. Clinical Cancer Research 11 4653-4657. (doi:10.1158/1078-0432.CCR-05-0525)

Tchédam Ngatcha B, Luu-The V, Labrie F \& Poirier D 2005 Androsterone $3 \alpha$-ether-3 $\beta$-substituted and androsterone $3 \beta$-substituted derivatives as inhibitors of type $317 \beta$-hydroxysteroid dehydrogenase: Chemical synthesis and structure-activity relationship. Journal of Medicinal Chemistry 48 5257-5268. (doi:10.1021/jm058179h)
Vicker N, Sharland CM, Heaton WB, Gonzalez AMR, Bailey HV, Smith A, Springall JS, Day JM, Tutill HJ, Reed MJ et al. 2009 The design of novel $17 \beta$-hydroxysteroid dehydrogenase type 3 inhibitors. Molecular and Cellular Endocrinology 301 259-265. (doi:10.1016/j.mce.2008.08.005) Vihko P, Herrala A, Harkonen P, Isomaa V, Kaija H, Kurkela R \& Pulkka A 2006 Control of cell proliferation by steroids: the role of 17HSDs. Molecular and Cellular Endocrinology 248 141-148. (doi:10.1016/j.mce. 2005.12.005)

Received in final form 4 October 2012

Accepted 6 November 2012

Made available online as an Accepted Preprint

6 November 2012
Published by Bioscientifica Ltd. 